\title{
Job-related Stress and Well-being Among Teachers: A Cross Sectional Study
}

\author{
Ruth Wong ${ }^{1}$ \\ ${ }^{1}$ Department of English Language Education, The Education University of Hong Kong, Hong Kong \\ Correspondence: Ruth Wong, The Education University of Hong Kong, 10 Lo Ping Road, Ta Po, Hong Kong. \\ Tel: 852-2948-8341. E-mail: wongmh@eduhk.hk
}

Received: January 16, 2020

doi:10.5539/ass.v16n5p19
Accepted: April 20, $2020 \quad$ Online Published: April 30, 2020

URL: https://doi.org/10.5539/ass.v16n5p19

\begin{abstract}
Teachers are believed to be a profession which brings relatively high job satisfaction as well as high level of stress in their job settings because of various reasons such as heavy workload, long teaching hours, large class size, students' disciplinary problems, cramped classrooms, excessive administrative work and so on. To examine what the main stressors are and whether gender and teaching experiences will make a difference on how teachers perceive job-related stress, this study has designed a questionnaire called Stress and Job Satisfaction Scale for Teacher (SJSST) to explore the issues. Results showed that school teachers faced moderate level of job-related stress. The main stressors were 'demands from job', 'work-life balance' and 'control over work'. It was also found that male teachers had higher level of stress in general. 'Psychosocial work environment', 'health \& well-being', and 'relations at work' were found to have significant difference between male and female teachers. According to the results of ANOVA, years of teaching experience were significant for all stressors. Teachers with more than 30 years of teaching experience received highest level of stress from 'demands from job' and 'work-life balance' among other groups of teachers. Teachers with 11-20 years of experience had highest level of stress from 'control over work' and 'psychosocial work environment'. While teachers with 6-10 years of experience, they suffered highest level of stress from 'health and well-being', 'future and change', 'relations at work', and 'physical environment'.
\end{abstract}

Keywords: stress, stressors, teachers, well-being

\section{Introduction}

Stress refers to physical, mental or emotional reactions and adjustment which body produces when changes occur (Kyriacou, 2001). Stress can be both positive and negative. Positive stress can keep a person motivated and aware of his surrounding environments like in a street or driving with cautiousness. However, stress can become negative if a person faces a prolonged period of stress without being able to release it, which in turn may cause distress - physical and emotional detrimental effect on the person like headaches, weight gain/loss, exhaustion, depression, and/or other forms of psychological illnesses (Fantuzzo et al., 2012). Among all jobs, one of the stressful jobs is teaching at school. According to Kyriacou (2001), teacher work stress reflects the undesirable psychological emotions stemmed from teaching and work-related duties inside and outside school.

Teachers are believed to be a profession which brings relatively high job satisfaction (Chaplain, 2008; Schwarzer \& Hallum, 2008) because a number of research indicated that teachers' job satisfaction came from direct interactions with students, witnessing student personal growth and development as well as academic outcomes (Crossman \& Harris, 2006; Turner, 2007). However, teachers are also believed to be highly stressed in their job settings (Johnson, Cooper, Cartwright, Taylor \& Millet, 2005). A wealth of empirical studies indicated that up to $1 / 3$ of teachers are highly stressed at work (Borg \& Riding, 1991; Geving, 2007; Thomas, Clark, \& Lavery, 2003) because of various reasons such as heavy workload (Chaplain, 2008; Klassen, \& Chiu, 2010), long teaching hours, large class size, students' disciplinary problems, cramped classrooms, excessive administrative work (Atkins et al., 2003; Barksdale-Ladd \& Thomas, 2000; Cappella, Frazier, Atkins, Schoenwald, \& Glisson, 2008; Shernoff et al., 2011), unsupportive senior management and parents (von der Embse, Kilgus, Solomon, Bowler \& Curtiss, 2015), and lack of support are the most common stressors (Michie \& Williams, 2003). It is believed that teacher stress consisted of job-related pressure, physical, psychological and emotional manifestations (Fimian \& Fastenau, 1990) which will in turn decrease the school effectiveness (Hung, 2012). 
These stressors are likely to have detrimental effects on teacher effectiveness, student-teacher relationship, mental as well as physical health which in turn traumatizing the quality of education in general. Specifically, stress can directly place negative influence on teachers' effectiveness and lead to poor teacher-student relationship and rapport (Abel \& Sewell, 1999). Teachers who suffer from immense stress from the teaching environment will be more prone to psychological anxiety (Ho \& Au, 2006). Meanwhile, teachers who suffer less stress from work and have higher job satisfaction will facilitate students' achievement and school effectiveness (Caprara, Barbaranelli, Steca, \& Malone, 2006). Positive school climate - positive relationship between teachers and school, mutual respect between teachers and senior management, and support from administrative staff - can bring psychological wellness to teachers and in turn positive learning outcomes for students (Cohen, McCabe, Michelli, \& Pickeral, 2009; Liu \& Ramsey, 2008).

In what way and to what extent teachers suffer from job-related stress are related to several teachers' characteristics such as gender, age and teaching experiences. Liu \& Ramsey (2008) found that female teachers perceived less job satisfaction than male teachers. Female teachers also suffered higher level of stress than male teachers (Antoniou, Polychroni, \& Vlachakis, 2006; Chaplain, 2008). Younger teachers with less teaching experience also perceived less job satisfaction (Klassen \& Chiu, 2010). However, scant previous studies had been conducted to examine how teachers' characteristics are related to the stress level they perceived. With the results of the study, education policy maker and school management may able to fine-tune the school work policy and explore opportunities to provide socio-emotional support to teachers to sustain their well-being.

\section{Research Questions}

This study aimed to answer the following questions:

1. What is the teachers' stress level?

2. What are the teachers' job-related stressors?

3. How does teachers' gender relate to job-related stress level and stressors?

4. To what extent teachers' years of teaching experience are related to their job-related stress level and stressors?

\section{Methods}

The main purpose of the current study was to examine the stress level of school teachers, what the main stressors are, and whether teachers' teaching experiences and gender are related to the stress level they have. Quantitative research is appropriate to serve the purpose of this study because the objectivity of the tests and analyses use descriptive, correlational and inferential statistics measure the degree of significant relationships and differences among different components.

\subsection{Sample}

The present study invited 54 schools of different districts in Hong Kong to take part in this study. 12 schools responded to the initial invite and 358 teachers expressed willingness to participate (Female 197 (55\%) Male 161 (45\%) this study. Participant teachers aged between 24 to 52, and had 2 years to 32 years of teaching experience. Table 1 shows the dispersion of the teachers' teaching experience.

Table 1. Dispersion of participant teachers' teaching experience $(\mathrm{N}=358)$

\begin{tabular}{ccc}
\hline Years of teaching experience & Number of teachers & Percentage \\
\hline Less than 5 years & 67 & $18.7 \%$ \\
$6-10$ years & 102 & $28.5 \%$ \\
$11-20$ years & 98 & $27.4 \%$ \\
$21-30$ years & 63 & $17.6 \%$ \\
Over 30 years & 28 & $7.8 \%$ \\
\hline
\end{tabular}

\subsection{Data Collection}

\subsubsection{Questionnaire}

A 73-item self-report questionnaire Stress and Job Satisfaction Scale for Teacher (SJSST) was designed to elicit responses from teachers regarding their work stress and satisfaction at work. It included items in relation to various components including physical work environment, demands from jobs, relationships at work, control over work, 
work-life balance, future and change, and health and well-being. All questionnaire items consisted of a six-point rating scale, from 1 (negative response) to 6 (positive response). To reduce response bias, 30 negative worded items were constructed in addition to 43 positive items (Hendra \& Hill, 2018). Pilot study was carried out to 15 teachers by convenient sampling. Unclear and ambiguous wordings were corrected after pilot study.

The questionnaire consisted of 8 parts with 73 questions in total (see Appendix 1 for all questions):

1. Physical work environment (7 questions)

2. Demands from the job (14 questions)

3. Relationship at work (5 questions)

4. Control over work (10 questions)

5. Work-life balance (2 questions)

6. Psychosocial work environment (13 questions)

7. Future and change (7 questions)

8. Health \& well-beings (16 questions)

Physical work environment refers to the school physical setting including, classroom size, staff room size, rest area available, tidiness of the campus, school facilities, and air quality of enclosed area. Demand from the job refers to the actual teaching load, job distribution, rest time, extracurricular activities, administration duties, communication with parents, counselling students, marking, lesson preparation, and professional training requirement. Relationship at work refers to whether teachers have good relationship with colleagues, students, parents and senior management. Control over work refers to meeting deadlines, school rules and regulations for teachers, initiative to schools, work targets and locus of control. Work life balance refers to whether teachers have time and energy for their own private life. Psychosocial work environment refers to teachers are satisfied that they are working with students and colleagues with fairness, meaningfulness, recognition, appreciation, acknowledgment, and a purpose. Future and change refers to whether they are worried about the foreseeable change in their work environment, like new teaching pedagogy, new and young staff joining the school, professional development and requirement. Health and well-being are to examine whether teachers are physically and emotionally healthy.

The online questionnaire link was sent to each participant school's link teacher who was the correspondent person with the researcher. The link teacher would then send the questionnaire link to the participant teachers via email. Teachers were given one week to respond. Prior to completing the survey, each teacher would also be asked to sign a consent form that described the nature of the study, the responses would only be used for this only study, and their identity would remain confidential. At the end of the questionnaire, teachers would only be asked to fill in their years of teaching experience, and gender.

\subsection{Data Analyses}

The responses from teacher questionnaires were mainly analysed by using SPSS. To answer RQ1 and RQ2, descriptive analyses were adopted for outlining the teachers' stress level and identifying the most significant stressors of teachers. After knowing the answers of RQ1 and 2. Further statistically tests were run to explore deeper and see if teachers' gender and years of teaching experience were correlated to their stress level and stressors.

To answer RQ3 to 6, various one-way analysis of variance (ANOVA) were used to see (1) if female and male teachers were significantly different from each other in relations to stress level (RQ3); (2) if female and male teachers were significantly different in relations to the identified stressors (RQ4); (3) if teachers with years of teaching experience were significantly different from one another in relations to stress level (RQ5); (4) if teachers with years of teaching experience were significantly different from one another in relations to the identified stressors (RQ6). If the results of ANOVA showed any significant effects and interaction between the variables, follow-up tests would be conducted to evaluate the differences. All statistical tests were set at $p<0.05$ significant level.

\section{Results}

The current study indicated that school teachers faced moderate level of job-related stress (M: 4.69, SD: 1.43) (see Table 2). The stressors were 'demands from job' (M: 1.22, SD: 0.28), 'work-life balance' (S: 1.36, M: 0.43), and 'control over work' (M: 2.04; M: 1.42). These three stressors all received negative responses with statistical means under 3.99 (with the use of 6-point likert scale). 
Table 2. Descriptive results of questionnaire (rank, means, standard deviation)

\begin{tabular}{|c|c|c|c|c|c|c|c|c|c|}
\hline & $\begin{array}{l}\text { Demands } \\
\text { from job }\end{array}$ & $\begin{array}{l}\text { Work-life } \\
\text { balance }\end{array}$ & $\begin{array}{c}\text { Control } \\
\text { over } \\
\text { work }\end{array}$ & $\begin{array}{l}\text { Psycho-social } \\
\text { work envir. }\end{array}$ & $\begin{array}{c}\text { Health \& } \\
\text { Well-being }\end{array}$ & $\begin{array}{c}\text { Future } \\
\& \\
\text { change }\end{array}$ & $\begin{array}{l}\text { Relations } \\
\text { at work }\end{array}$ & $\begin{array}{c}\text { Physical } \\
\text { work } \\
\text { envir. }\end{array}$ & Average \\
\hline \multirow{2}{*}{$\begin{array}{c}\text { All } \\
\text { teachers }\end{array}$} & 1 & 2 & 3 & 4 & 5 & 6 & 7 & 8 & \\
\hline & $\begin{array}{c}1.22 \\
(0.58)\end{array}$ & $\begin{array}{c}1.36 \\
(0.86)\end{array}$ & $\begin{array}{c}2.04 \\
(1.42)\end{array}$ & $\begin{array}{c}4.07 \\
(1.25)\end{array}$ & $\begin{array}{c}4.12 \\
(1.62)\end{array}$ & $\begin{array}{c}4.77 \\
(1.77)\end{array}$ & $\begin{array}{c}5.23 \\
(1.52)\end{array}$ & $\begin{array}{c}5.33 \\
(1.16)\end{array}$ & $\begin{array}{c}4.69 \\
(1.51)\end{array}$ \\
\hline \multirow{2}{*}{$\begin{array}{l}\text { Female } \\
\text { teachers }\end{array}$} & 1 & 2 & 4 & 3 & 5 & 6 & 7 & 8 & \\
\hline & $\begin{array}{c}1.32 \\
(0.41)\end{array}$ & $\begin{array}{c}1.34 \\
(0.45)\end{array}$ & $\begin{array}{c}2.04 \\
(1.23)\end{array}$ & $\begin{array}{c}2.65 \\
(1.28)\end{array}$ & $\begin{array}{c}3.02 \\
(1.89)\end{array}$ & $\begin{array}{c}4.64 \\
(1.66)\end{array}$ & $\begin{array}{c}4.92 \\
(2.08)\end{array}$ & $\begin{array}{c}5.22 \\
(1.15)\end{array}$ & $\begin{array}{c}4.19 \\
(1.48)\end{array}$ \\
\hline \multirow{2}{*}{$\begin{array}{c}\text { Male } \\
\text { teachers }\end{array}$} & 1 & 3 & 4 & 2 & 6 & 5 & 7 & 8 & \\
\hline & $\begin{array}{c}1.10 \\
(0.68)\end{array}$ & $\begin{array}{c}1.38 \\
(1.01)\end{array}$ & $\begin{array}{c}2.04 \\
(1.45)\end{array}$ & $\begin{array}{c}5.81 \\
(1.24)\end{array}$ & $\begin{array}{c}5.47 \\
(1.36)\end{array}$ & $\begin{array}{c}4.92 \\
(1.98)\end{array}$ & $\begin{array}{c}5.61 \\
(1.15)\end{array}$ & $\begin{array}{c}5.47 \\
(1.19)\end{array}$ & $\begin{array}{c}5.30 \\
(1.62)\end{array}$ \\
\hline \multirow{2}{*}{$\begin{array}{c}>5 \\
\text { years }\end{array}$} & 1 & 3 & 2 & 5 & 4 & 8 & 6 & 7 & \\
\hline & $\begin{array}{c}1.04 \\
(1.26)\end{array}$ & $\begin{array}{c}1.09 \\
(1.68)\end{array}$ & $\begin{array}{c}1.08 \\
(1.06)\end{array}$ & $\begin{array}{c}5.02 \\
(2.14)\end{array}$ & $\begin{array}{c}2.83 \\
(2.63)\end{array}$ & $\begin{array}{c}5.08 \\
(1.26)\end{array}$ & $\begin{array}{c}5.04 \\
(1.49)\end{array}$ & $\begin{array}{c}5.06 \\
(1.22)\end{array}$ & $\begin{array}{c}4.37 \\
(1.89)\end{array}$ \\
\hline \multirow{2}{*}{$\begin{array}{c}6-10 \\
\text { years }\end{array}$} & 1 & 2 & 3 & 4 & 5 & 7 & 6 & 8 & \\
\hline & $\begin{array}{c}1.12 \\
(1.42)\end{array}$ & $\begin{array}{c}1.15 \\
(1.26)\end{array}$ & $\begin{array}{l}2.32 \\
(2.24)\end{array}$ & $\begin{array}{c}4.45 \\
(2.48)\end{array}$ & $\begin{array}{c}5.50 \\
(1.49)\end{array}$ & $\begin{array}{c}5.55 \\
(1.15)\end{array}$ & $\begin{array}{c}5.54 \\
(1.19)\end{array}$ & $\begin{array}{c}5.89 \\
(1.16)\end{array}$ & $\begin{array}{c}5.24 \\
(1.98)\end{array}$ \\
\hline \multirow{2}{*}{$\begin{array}{l}11-20 \\
\text { years }\end{array}$} & 1 & 2 & 3 & 5 & 4 & 6 & 7 & 8 & \\
\hline & $\begin{array}{c}1.31 \\
(1.26)\end{array}$ & $\begin{array}{c}1.32 \\
(1.14)\end{array}$ & $\begin{array}{c}3.01 \\
(2.61)\end{array}$ & $\begin{array}{c}5.38 \\
(1.86)\end{array}$ & $\begin{array}{c}3.28 \\
(1.23)\end{array}$ & $\begin{array}{c}5.39 \\
(1.08)\end{array}$ & $\begin{array}{c}5.73 \\
(1.27)\end{array}$ & $\begin{array}{c}5.62 \\
(2.08)\end{array}$ & $\begin{array}{c}5.26 \\
(1.64)\end{array}$ \\
\hline \multirow{2}{*}{$\begin{array}{l}21-30 \\
\text { years }\end{array}$} & 1 & 4 & 2 & 3 & 6 & 5 & 7 & 8 & \\
\hline & $\begin{array}{c}1.28 \\
(1.19)\end{array}$ & $\begin{array}{c}1.33 \\
(1.58)\end{array}$ & $\begin{array}{c}1.30 \\
(1.48)\end{array}$ & $\begin{array}{c}1.32 \\
(1.08)\end{array}$ & $\begin{array}{c}5.12 \\
(1.78)\end{array}$ & $\begin{array}{c}2.98 \\
(2.63)\end{array}$ & $\begin{array}{c}5.14 \\
(1.69)\end{array}$ & $\begin{array}{c}5.25 \\
(1.29)\end{array}$ & $\begin{array}{c}3.95 \\
(1.48)\end{array}$ \\
\hline \multirow{2}{*}{$\begin{array}{c}<30 \\
\text { years }\end{array}$} & 1 & 6 & 2 & 3 & 4 & 7 & 5 & 8 & \\
\hline & $\begin{array}{c}1.57 \\
(1.69)\end{array}$ & $\begin{array}{c}3.01 \\
(2.89)\end{array}$ & $\begin{array}{c}1.58 \\
(2.01)\end{array}$ & $\begin{array}{c}2.01 \\
(1.28)\end{array}$ & $\begin{array}{c}2.86 \\
(1.09)\end{array}$ & $\begin{array}{c}3.02 \\
(2.07)\end{array}$ & $\begin{array}{c}3.00 \\
(2.38)\end{array}$ & $\begin{array}{c}3.10 \\
(1.63)\end{array}$ & $\begin{array}{c}3.36 \\
(1.99)\end{array}$ \\
\hline
\end{tabular}

It was also found that male teachers had higher level of stress in general (M: 5.30, $p<0.001$ ). Of all the stressors, female teachers received more stress from 'demands from jobs' but the result did not demonstrate statistical significance difference. Male teachers were found to have higher stress levels received from 'psychosocial work environment', 'health \& well-being', and 'relations at work' which were with significant difference, while 'work-life balance' 'future and change' and 'physical work environment' did not demonstrate significant difference (see Table 3).

Table 3. Comparison of female and make teachers

\begin{tabular}{|c|c|c|c|c|c|c|c|c|}
\hline & \multicolumn{3}{|c|}{ Mean } & \multicolumn{3}{|c|}{ SD } & \multicolumn{2}{|c|}{$t$-test } \\
\hline & All & Male & Female & All & Male & Female & $t$-value & Sig. \\
\hline Stress level & 4.69 & 5.30 & 4.19 & 1.51 & 1.62 & 1.48 & 2.43 & $p<0.001$ \\
\hline Demands from job & 1.22 & 1.10 & 1.32 & 0.58 & 0.68 & 0.41 & 2.48 & NS \\
\hline Work-life balance & 1.36 & 1.38 & 1.34 & 0.86 & 1.01 & 0.45 & 1.49 & NS \\
\hline Control over work & 2.04 & 2.04 & 2.04 & 1.42 & 1.45 & 1.23 & 2.69 & NS \\
\hline Psychosocial work environment & 4.07 & 5.81 & 2.65 & 1.25 & 1.28 & 1.24 & 2.98 & $p<0.001$ \\
\hline Health \& well-being & 4.12 & 5.47 & 3.02 & 1.62 & 1.36 & 1.89 & 2.48 & $p<0.001$ \\
\hline Future \& change & 4.77 & 4.92 & 4.64 & 1.77 & 1.98 & 1.66 & 2.21 & NS \\
\hline Relations at work & 5.23 & 5.61 & 4.92 & 1.52 & 1.15 & 2.08 & 1.96 & $p<0.001$ \\
\hline Physical work environment & 5.33 & 5.47 & 5.22 & 1.16 & 1.19 & 1.15 & 2.49 & NS \\
\hline
\end{tabular}


The descriptive results found that teachers with more than 30 years of teaching experience received highest level of stress from 'demands from job' and 'work-life balance' among other groups of teachers. Teachers with 11-20 years of experience had highest level of stress from 'control over work' and 'psychosocial work environment'. While teachers with 6-10 years of experience, they suffered highest level of stress from 'health and well-being', 'future and change', 'relations at work', and 'physical environment' (see table 4). According to the results of ANOVA, years of teaching experience were significant for all stressors: demands from job, work-life balance $F(5,350)=2.34, p<0.05$, partial $\eta^{2}=0.01$; work life balance $F(5,350)=2.48, p<0.05$, partial $\eta^{2}=0.01$; control over work $F(5,350)=4.44, p<0.05$, partial $\eta^{2}=0.01$; psychosocial work environment $F(5,350)=5.61$, $p<0.05$, partial $\eta^{2}=0.01$; health and well-being $F(5,350)=4.05, p<0.05$, partial $\eta^{2}=0.01$; future and change $F(5,350)=2.89, p<0.05$, partial $\eta^{2}=0.01$; relations at work $F(5,350)=2.12, p<0.05$, partial $\eta^{2}=0.01$; physical work environment $F(5,350)=2.08, p<0.05$, partial $\eta^{2}=0.01$.

Table 4. One-way analysis pf variance tale comparing means, standard deviations and effect sizes on stressors by years of teaching experience

\begin{tabular}{|c|c|c|c|c|c|}
\hline & & & & ANOVA & Effect Size \\
\hline Stressors & Teaching experience & Mean & SD & $F$-value & Partial $\eta^{2}$ \\
\hline \multirow{5}{*}{ Demands from job } & $>5$ years & 1.04 & 1.26 & \multirow{5}{*}{$2.21 *$} & \multirow{5}{*}{0.01} \\
\hline & $6-10$ years & 1.12 & 1.42 & & \\
\hline & $11-20$ years & 1.31 & 1.26 & & \\
\hline & 21-30 years & 1.28 & 1.19 & & \\
\hline & $<30$ years & 1.57 & 1.69 & & \\
\hline \multirow{5}{*}{ Work-life balance } & $>5$ years & 1.09 & 1.68 & \multirow{5}{*}{$2.48^{*}$} & \multirow{5}{*}{0.01} \\
\hline & $6-10$ years & 1.15 & 1.26 & & \\
\hline & $11-20$ years & 1.32 & 1.14 & & \\
\hline & $21-30$ years & 1.33 & 1.58 & & \\
\hline & $<30$ years & 3.01 & 2.89 & & \\
\hline \multirow{5}{*}{ Control over work } & $>5$ years & 1.08 & 1.06 & \multirow{5}{*}{$4.44 * *$} & \multirow{5}{*}{0.02} \\
\hline & $6-10$ years & 2.32 & 2.24 & & \\
\hline & $11-20$ years & 3.01 & 2.61 & & \\
\hline & 21-30 years & 1.30 & 1.48 & & \\
\hline & $<30$ years & 1.58 & 2.01 & & \\
\hline \multirow{5}{*}{$\begin{array}{c}\text { Psychosocial } \\
\text { work environment }\end{array}$} & $>5$ years & 5.02 & 2.14 & \multirow{5}{*}{$5.61 * * *$} & \multirow{5}{*}{0.03} \\
\hline & $6-10$ years & 4.45 & 2.48 & & \\
\hline & $11-20$ years & 5.38 & 1.86 & & \\
\hline & 21-30 years & 1.32 & 1.08 & & \\
\hline & $<30$ years & 2.01 & 1.28 & & \\
\hline \multirow{5}{*}{ Health \& well-being } & $>5$ years & 2.83 & 2.63 & \multirow{5}{*}{$4.05 * *$} & \multirow{5}{*}{0.02} \\
\hline & $6-10$ years & $\mathbf{5 . 5 0}$ & 1.49 & & \\
\hline & $11-20$ years & 3.28 & 1.23 & & \\
\hline & 21-30 years & 5.12 & 1.78 & & \\
\hline & $<30$ years & 2.86 & 1.09 & & \\
\hline \multirow{5}{*}{ Future \& change } & $>5$ years & 5.08 & 1.26 & \multirow{5}{*}{$2.89 * *$} & \multirow{5}{*}{0.02} \\
\hline & $6-10$ years & 5.55 & 1.15 & & \\
\hline & $11-20$ years & 5.39 & 1.08 & & \\
\hline & 21-30 years & 2.98 & 2.63 & & \\
\hline & $<30$ years & 3.02 & 2.07 & & \\
\hline
\end{tabular}




\begin{tabular}{cccccc}
\hline & $>5$ years & 5.04 & 1.49 & & \\
6-10 years & $\mathbf{5 . 5 4}$ & 1.19 & & \\
Relations at work & $11-20$ years & 5.73 & 1.27 & $2.12^{*}$ & 0.01 \\
& $21-30$ years & 5.14 & 1.69 & & \\
& $<30$ years & 3.00 & 2.38 & \\
Physical work environment & $>5$ years & 5.06 & 1.22 & & \\
& 6-10 years & $\mathbf{5 . 8 9}$ & 1.16 & & \\
& $11-20$ years & 5.62 & 2.08 & $2.08^{*}$ & 0.01 \\
& $21-30$ years & 5.25 & 1.29 & & \\
\hline
\end{tabular}

*** Significance at the 0.001 level. ** Significance at the 0.01 level. $\quad *$ Significance at the 0.05 level.

\section{Discussion \& Implication}

The current study indicated that school teachers faced moderate level of job-related stress. The main stressors were 'demands from job', 'work-life balance' and 'control over work'. The relationships of these stressors can be seen as causes and effects. That is, excessive demands from job led to teachers' not being able to control over work and have a balance between life and work. To stop the situation from worsening, implementing intervention to reduce teacher stress will be feasible. Interventions can be divided into 3 levels: school intervention to improve school's culture; school-teacher interface intervention to improve communications between senior management and teachers; and finally teacher interventions that help teachers' develop strategies on stress and mindfulness management as past studies had shown training teachers to deal with stress would improve job-satisfaction (Beshai, McAlpine, Weare \& Kuyken, 2016).

It was also found that male teachers had higher level of stress in general. 'Psychosocial work environment', 'health \& well-being', and 'relations at work' were found to have significant difference between male and female teachers. However, these results should be interpreted with caution as the current study may only contribute a small part to the body of literature. Past studies have demonstrated contradictory results. For example, Aftab \& Khatoon (2012) found that male teachers experienced more stress compared to female teachers, while Check \& Okwo (2012) found that teachers feel stressful regardless of their gender because teachers feel stress mainly due to external factors rather than personal traits. However, what can be ascertained is that male teachers found psychosocial environment posed greatest stress to them which may have brought detrimental consequences on their health and mindfulness as supported by the current study.

Years of teaching experience were also found to be significant for all stressors which echoed the results of past studies like Kemeny (2003) and Balakrishnamurthy \& Shanker (2009). Teachers with different teaching experiences received different sources of stress-teachers with more than 30 years of teaching experience received highest level of stress from 'demands from job' and 'work-life balance' among other groups of teachers. Teachers with 11-20 years of experience had highest level of stress from 'control over work' and 'psychosocial work environment'. While teachers with 6-10 years of experience, they suffered highest level of stress from 'health and well-being', 'future and change', 'relations at work', and 'physical environment'. To understand why certain groups of teachers were more prone to suffer certain sources of stress deserves further research to identify its complex nature and relationship.

\section{Limitations}

The current study presented several significant findings for further research. However, limitations of study still existed including the small sample size $(\mathrm{N}=356)$ and the study was only restricted to Asian educational context. The study could also adopt mixed method and include in-depth interviews with participants to capture the fluidity of the psychological state of the teachers' mind in order to show a more holistic picture of the issue.

\section{Conclusion}

Teaching has been considered as a challenging yet satisfying career. Mental health of teachers has also been a focus for research because of the because of various reasons such as heavy workload, long teaching hours, large class size, students' disciplinary problems, cramped classrooms, excessive administrative work and so on. This study showed that teachers received moderate level of stress and the main stressors were 'demands from job', 
'work-life balance' and 'control over work'. It was also found that male teachers had higher level of stress in general. 'Psychosocial work environment', 'health \& well-being', and 'relations at work' were found to have significant difference between male and female teachers. Years of teaching experience were also found to be significant for all stressors. Teachers with more than 30 years of teaching experience received highest level of stress from 'demands from job' and 'work-life balance' among other groups of teachers. Teachers with 11-20 years of experience had highest level of stress from 'control over work' and 'psychosocial work environment'. While teachers with 6-10 years of experience, they suffered highest level of stress from 'health and well-being', 'future and change', 'relations at work', and 'physical environment'. It is suggested that interventions should be implemented to school to prevent the current situations from worsening. Levels of interventions include 'school intervention'- to fine-tune school culture, 'school-teacher intervention'-to improve communication between school and teachers, and 'teacher intervention'-to help teachers develop strategies on stress management.

\section{References}

Abel, M., \& Sewell, J. (1999). Stress and burnout in rural and urban secondary school teachers. Journal of Educational Research, 92, 287-293. https://doi.org/10.1080/00220679909597608

Aftab, M., \& Khatoon, T. (2012). Demographic differences and occupational stress of secondary school teachers. European Scientific Journal, 8(5), 159-175.

Antoniou, A.-S., Polychroni, F., \& Vlachakis, A.-N. (2006). Gender and age differences in occupational stress and professional burnout between primary and high-school teachers in Greece. Journal of Managerial Psychology, 21, 682-690.

Atkins, M., Graczyk, P., Frazier, S., \& Adil, J. (2003). Toward a new model for school-based mental health: Accessible, effective, and sustainable services in urban communities. School Psychology Review, 32, 503-514.

Balakrishnamurthy, C., \& Shankar, S. (2009). Impact of age and level of experience on occupational stress experienced by non-gazetted officers of the central reserve police force. Industrial Psychiatry Journal, 18(2), 81-83. https://doi.org/10.4103/0972-6748.62264

Barksdale-Ladd, M. A., \& Thomas, K. F. (2000). What's at stake in high-stakes testing teachers and parents speak out. Journal of Teacher Education, 51(5), 384-397. https://doi.org/10.1177/0022487100051005006

Hendal, R., \& Hill, A. (2018). Rethinking response rates: New evidence of little relationship between survey response rates and nonresponse bias. Evaluation Review, 23, 1-24. https://doi.org/10.1177/0193841X18807719

Beshai, S., McAlpine, L., Weare, K., \& Kuyken, W. (2016). A non-randomised feasibility trial assessing the efficacy of a mindfulness-based intervention for teachers to reduce stress and improve well-being. Mindfulness, 7(1), 198-208. https://doi.org/10.1007/s12671-015-0436-1

Borg, M. G., \& Riding, R. J. (1991). Stress in teaching: A study of occupational stress and its determinants, job satisfaction and career commitment among primary schoolteachers. Educational Psychology, 11, 59. https://doi.org/10.1080/0144341910110104

Cappella, E., Frazier, S. L., Atkins, M. S., Schoenwald, S. K., \& Glisson, C. (2008). Enhancing schools' capacity to support children in poverty: An ecological model of school-based mental health services. Administration and Policy in Mental Health, 35, 395-409. https://doi.org/10.1007/s10488-008-0182-y

Caprara, G. V., Barbaranelli, C., Steca, P., \& Malone, P. S. (2006). Teachers' self-efficacy beliefs as determinants of job satisfaction and students' academic achievement: A study at the school level. Journal of School Psychology, 44, 473-490. https://doi.org/10.1016/j.jsp.2006.09.001

Chaplain, R. P. (2008). Stress and psychological distress among trainee secondary teachers in England. Educational Psychology, 28(2), 195-209. https://doi.org/10.1080/01443410701491858

Check, R. F. E. \& Okwo, F. A. (2012). Influence of demographic factors on stress perceptions of teachers of public secondary schools in Cameroon. Procedia Social and Behavioral Sciences, 47, 439-443. https://doi.org/10.1016/j.sbspro.2012.06.677

Cohen, L., Manion, L., \& Morrison, K. (2018). Research Methods in Education. London: Routledge.

Cohen, J., McCabe, E. M., Michelli, N. M., \& Pickeral, T. (2009). School climate: Research, policy, practice, and teacher education. Teachers College Record, 111, 180-213.

Crossman, A., \& Harris, P. (2006). Job satisfaction of secondary school teachers. Educational Management 
Administration \& Leadership, 34(1), 29-46. https://doi.org/10.1177/1741143206059538

Fantuzzo, J., Perlman, S., Sproul, F., Minney, A., Perry, M. A., \& Li, F. (2012). Making visible teacher reports of their teaching experiences: The early childhood teacher experiences scale. Psychology in the Schools, 49(2), 194-205. https://doi.org/10.1002/pits.20623

Fimian, M. J., \& Fastenau, P. S. (1990). The validity and reliability of the teacher stress inventory: A re-analysis of aggregate data. Journal of Organizational Behavior, 11(2), 151-157.

Geving, A. M. (2007). Identifying the types of student and teacher behaviors associated with teacher stress. Teaching and Teacher Education, 23, 624-640. https://doi.org/10.1016/j.tate.2007.02.006

Ho, C. \& Au, W. (2006). Teaching satisfaction scale: Measuring job satisfaction of teachers. Educational and Psychological Measurement, 66(1), 172-185. https://doi.org/10.1177/0013164405278573

Hung, C. (2012). Internal marketing, teacher job satisfaction, and effectiveness of central Taiwan primary schools. Social Behavior and Personality, 40(9), 1435-1450. https://doi.org/10.2224/sbp.2012.40.9.1435

Johnson, S., Cooper, C., Cartwright, S., Donald, I., Taylor, P., \& Millet, C. (2005). The experience of work-related stress across occupations. Journal of Managerial Psychology, 20(2), 178-187. https://doi.org/10.1108/02683940510579803

Kemeny, M. E. (2003). The Psychobiology of stress. Current Directions in Psychological Science, 12(4), 124-129. https://doi.org/10.1111/1467-8721.01246

Kidger, J., Brockman, R., Tilling, K., Campbell, R., Ford, T., Araya, R., King, M., \& Gunnell, D. (2016). Teachers' wellbeing and depressive symptoms, and associated risk factors: A large cross- sectional study in English secondary schools. Journal of Affective Disorders, 192, 76-82. https://doi.org/10.1016/j.jad.2015.11.054

Klassen, R. M., \& Chiu, M. M. (2010). Effects on teachers' self-efficacy and job satisfaction: Teacher gender, years of experience, and job stress. Journal of Educational Psychology, 102, 741-756. https://psycnet.apa.org/buy/2010-15712-016

Kyriacou, C. (2001). Teacher stress: Directions for future research. Educational Review, 53(1), 27-35. https://doi.org/10.1080/00131910120033628

Liu, X. S., \& Ramsey, J. (2008). Teachers' job satisfaction: Analyses of the teacher follow-up survey in the United States for 2000-2001. Teaching and Teacher Education, 24, 1173-1184. https://doi.org/10.1016/j.tate.2006.11.010

\section{Appendix 1 Stress and Job Satisfaction Scale for Teacher (SJSST)}

Physical work environment

1. Is the staff room spacious?

2. Can you find space to take a break at school if needed?

3. Is the staff room clean?

4. Are the facilities at schools sufficient for work?

5. Is the staff room comfortable?

6. Are the classrooms cramped? $\mathrm{R}$

7. Is the air in the classroom fresh?

Demands from the job

1. Is work distributed fairly?

2. Do you think you work adequate number hours?

3. Do you think you are over-worked? $\mathrm{R}$

4. Do you have sufficient time to work?

5. Do you have enough breaks from work?

6. Do you think you are over-teaching? $\mathrm{R}$

7. Do you have enough time for planning your lesson? 
8. Does counselling students take up too much of your work time? R

9. Do extra-curricular activities take up too much of your work time? $\mathrm{R}$

10. Is your administrative work too much? $\mathrm{R}$

11. Do you feel stressed that the government requires all teachers to achieve the number of hours professional development activities? $\mathrm{R}$

12. Do you have sufficient time for marking?

13. Do you think dealing and communicating with parents has taken up too much of your work time? $\mathrm{R}$

14. Are the number of meetings at school adequate?

Relationship at work

1. Do you have a positive relationship with your colleagues?

2. Are you able to build a rapport with your students?

3. Do you have a healthy relationship with the senior management at school?

4. Do you have a friendly relationship with the parents?

5. Do you think you have a friendly work environment?

Control over work

1. Do you feel incapable of controlling over work? $\mathrm{R}$

2. Are there unrealistic target from work? R

3. Are you able to keep up with the work pace?

4. Are you given enough time to meet the deadlines?

5. Are you over-supervised? $\mathrm{R}$

6. Do you have enough freedom in making own decisions at work?

7. Do you feel that there are too many rules and regulations for teachers at school? $\mathrm{R}$

8. Do you get behind with your work? $\mathrm{R}$

9. Can you influence the amount of work assigned to you?

10. Are your initiatives and suggestions usually taken and heard by the senior management?

Work-life balance

1. Do you think your work drains so much of your energy that it has a negative impact on your private life (i.e. families, hobbies...etc)? R

2. Do you think your work drains so much of your time that it has a negative impact on your private life (i.e. families, hobbies...etc)? R

Psychosocial work environment

1. Do you think your work is meaningful?

2. Do you feel that what you do at work is important?

3. Are you treated fairly at work?

4. Is your work well-acknowledged and recognized by the students?

5. Is your work appreciated by the senior management?

6. Do you colleagues appreciate what you do at work?

7. Are you pleased with your work?

8. Are you satisfied with your work?

9. Do you have a clear objective at work?

10. Would you recommend your friends to become a teacher?

11. Does your work put you in a difficult emotional status? $\mathrm{R}$

12. Do you work at a high pace throughout the day? $\mathrm{R}$ 
13. Do you think you are adequately paid?

Future and change

1. Are you worried about curriculum change? $\mathrm{R}$

2. Do you find it difficult to find time to take professional development courses? $\mathrm{R}$

3. Are you optimistic about your career?

4. Are you worried about job security? R

5. Are you worried about the change of management personnel (e.g. principal, vice-principal, panel chairperson...etc)? R

6. Are you worried about your ability on keeping up with the latest teaching methods including e-learning? R

7. Are you worried that colleagues of younger age or with less experience will be your superior? $\mathrm{R}$

Health and well-being

1. Are you physically healthy?

2. Are you in general happy?

3. Are you emotionally healthy?

4. Do you feel worn out? R

5. Do you frequently feel stressed? $\mathrm{R}$

6. Do you easily feel irritated? $\mathrm{R}$

7. Are you feeling positively?

8. Do you suffer from frequent headaches from work? $\mathrm{R}$

9. $\quad$ Are you depressed? R

10. Do you think you are suffering potential psychological illnesses? $\mathrm{R}$

11. Do you have 8 hours of sleep every day?

12. Is your digestion fine?

13. Do you have continual tiredness? $\mathrm{R}$

14. Are you motivated?

15. Is your concentration fair enough?

\section{Copyrights}

Copyright for this article is retained by the author(s), with first publication rights granted to the journal.

This is an open-access article distributed under the terms and conditions of the Creative Commons Attribution license (http://creativecommons.org/licenses/by/4.0/). 